\title{
Ex-Situ vs. In-Situ Defluoridation of the Contaminated Aquifers: A State-of-the-Art Review
}

\author{
Meenakshi Arora*, Nibha Gupta ${ }^{\#}$ \\ *Dept. of Infrastructure Engineering. The University of Melbourne, Victoria, Australia \\ \#Dept. of Chemical Engineering. Indian School of Mines, Dhanbad, Jharkhand, India
}

\begin{abstract}
A wide variety of pump and treat methods like chemical precipitation, adsorption, ion exchange and reverse osmosis have been trialled for many decades for fluoride removal from groundwater, but the problem of fluoride contaminated water remains in many parts of the world largely because these processes require constant monitoring, are expensive to implement and maintain at decentralised scale due to lack of reticulation infrastructure, and possess sludge disposal problem. This paper presents an overview of various fluoride removal processes and the limitations associated with each process and the application of in-situ permeable reactive barrier for remediating fluoride contaminated groundwater is explored, which displays the potential to be a cost effective, low maintenance and energy intensive technology.
\end{abstract}

Keywords: Fluoride, groundwater, in-situ remediation, pump and treat

\section{BACKGROUND}

Fluoride has been identified as one of the most widespread endemic health problems associated with natural geochemistry (Brindha et al., 2011; Jha et al., 2011; Loganathan et al., 2013; Majumdar, 2011; Oruc, 2008; Tekle-Haimanot et al., 1995). High concentration of fluoride is found in groundwater due to seepage of water through crystalline rocks containing fluorinerich minerals, especially granites and volcanic rocks(British Geological Survey, 2012) . It's often considered as double edged sword as at low concentration, fluoride prevents dental caries and tooth decay but at higher levels it has various detrimental health impacts for humans as well as animals (Fawell \& Bailey, 2006; Jha et al., 2011; Mohapatra et al., 2009). The EPA's National Health and Environmental Effects Research Laboratory have classified fluoride as a "chemical having substantial evidence of developmental neurotoxicity" at concentration higher than permissible limit (Mercola, 2015). The 1984 WHO guideline value for fluoride in drinking water is $1.5 \mathrm{mg} / \mathrm{l}$ (Edmunds \& Smedley, 2013) and is also the Australian recommended limit (The Univerisity of Adelaide, 2012; Yeung, 2008). At concentration above $1.5 \mathrm{mg} / \mathrm{l}$, mottling of teeth may occur to an objectionable degree, while concentrations between 3 and $6 \mathrm{mg} / \mathrm{l}$ may cause skeletal fluorosis (Edmunds \& Smedley, 2013). Continued consumption of water with fluoride levels in excess of $10 \mathrm{mg} / \mathrm{l}$ can result in crippling fluorosis (Edmunds \& Smedley, 2013).

High level of fluoride has been reported in 28 nations around the globe (British Geological Survey, 2012; Habuda-Stanić et al., 2014; Majumdar, 2011; Oruc, 2008; Tekle-Haimanot et al., 1995). These belts span over 14 countries in Africa, 8 countries in Asia, and 6 countries in the America having water considered unsafe by the World Health Organization (WHO) (TekleHaimanot et al., 1995). Groundwater fluoride level is greater than $4 \mathrm{mg} / \mathrm{l}$ in many parts of the world (Habuda-Stanić et al., 2014; Oruc, 2008; Thole, 2013) and levels as high as $30 \mathrm{mg} / \mathrm{l}$ have been reported (Habuda-Stanić et al., 2014). Data from India's Union Health and Family Welfare Ministry indicate that nearly 49 million people are living in areas where fluoride levels in 
groundwater are above the permissible levels (Mercola, 2015). Australia has 25,780 GL of groundwater suitable for potable, stock and domestic use, and irrigated agriculture that can be extracted sustainably each year but due to high level of fluoride (up to $13.5 \mathrm{ppm}$ ) only arid zones of South Australia, the Northern Territory, and the Pilbara are entirely dependent on groundwater (Jagtap et al., 2012; Thiruvenkatachari et al., 2008). In contrast, drinking water supply in many developed countries has long been fluoridated to prevent dental caries and tooth decay (American Public Health Association, 2008; Canadian Dental Association, 2012; Canadian Dental Association, 2013; Carmona, 2004; Cross, 2013; McDonagh et al., 2000).

The Excessive ongoing consumption of fluoride can also lead to manifestations such as gastrointestinal, neurological, and urinary problems (Edmunds \& Smedley, 2013; Ibrahim et al., 2011; Jha et al., 2011). Researchers have suggested the provision of alternate source of water, transporting water from distant sources, blending high fluoride with low fluoride water, dual water sources, rainwater harvesting etc. as a measure to prevent purifying fluoride contaminated groundwater (MacDonald \& Kavanaugh, 1994). But if the alternative water is not available, the best method of mitigating fluorosis is to implement defluoridation techniques in the affected areas. Various pump and treat techniques have been employed in different parts of the world to remove fluoride from groundwater by utilising various materials, but most of these techniques are very site specific, require ongoing monitoring and maintenance, which make it very difficult to implement at household or community scale due to lack of centralized infrastructure. In situ processes that attempt to remove fluoride within the aquifer are seen to have a substantial potential to minimize the operational and maintenance issue (Teutsch et al., 1996; Thiruvenkatachari et al., 2008; Tredoux et al., 2004). This paper presents an overview of the current state-of-art on various pump and treat methods as well as in situ methods for fluoride removal from underground water and the opportunities and challenges associated with each process. The paper also identifies the major gaps in the current knowledge and the areas for future research.

\section{PUMP AND TREAT DEFLUORIDATION TECHNIQUES}

Pump and treat method involves pumping the groundwater on the surface and removing fluoride using various chemical or physical processes at household, community or precinct scale. Defluoridation process employed in a particular region depends on various factors such as quality of groundwater, geological structure of the area, $\mathrm{pH}$ range, temperature of water and various other factors. The most commonly employed methods for pump and treat system are chemical precipitation, sorption, membranes and ion exchange resins. A brief summary of these methods including the benefits and challenges as discussed in literature is presented below:

\section{Chemical Precipitation Method}

The Chemical precipitation method involves the use of chemicals for converting the dissolved/colloidal/suspended impurities into an insoluble precipitate/co-precipitate that is removed from liquid phase by filtration. Various types of chemical precipitation and coprecipitation methods have been used as a measure to treat water contaminated with fluorine (Feenstra et al., 2007; Mishra et al., 2010).

Addition of lime with aluminium or magnesium has been the most frequently used chemical for precipitation/co precipitation (BGS 2012). Lime and magnesium are not preferred as it increases the $\mathrm{pH}$ of the water making it unfit for consumption (Lyengar,1996). Addition of lime with aluminium is commonly known as the Nalgonda process developed by National Environmental Engineering Research Institute (British Geological Survey, 2012; Dahi et al., 
1996). Nalgonda technique has been considered the cheapest, the easiest to operate and that it can be carried out by using locally available materials (Matsuura \& Sourirajan, 1972; Piddennavar \& Krishnappa, 2013; Suneetha et al., 2008). In Tanzania where very high level of fluoride $(24 \mathrm{mg} / \mathrm{L})$ has been reported in underground water, Nalgonda process is one of the most practiced process (Tekle-Haimanot et al., 1995).

The process has been thoroughly researched but still it possesses various problems like generation of acidic or alkaline water, residual soluble aluminium and aluminium fluoride complexes and fluoride contaminated sludge (Gill et al.,2004 ; Nagendra Rao, 2003). In addition, the efficiency being dependent on the raw water quality, in particular the fluoride concentration, $\mathrm{pH}$ and alkalinity, further limits its practical applications at smaller scales (Gill et al.,2004; Nagendra Rao, 2003). Lime is unsuitable for field application as it has high initial cost, large dosage is required and also make the water alkaline. Alum is known to cause Alzheimer's in the western parts of India (Gill et al.,2004 ; Nagendra Rao, 2003).

\section{Adsorption}

Adsorption involves the passage of fluoride contaminated water through a contact bed filled with adsorbent material where fluoride gets adsorbed on the filter bed and clean water can be collected from the other end. The different adsorbents used for fluoride removal include activated alumina, carbon, bone charcoal, activated alumina coated silica gel, calcite, activated saw dust, magnesia, serpentine, tricalcium phosphate, activated soil sorbents, carbion, defluoron, and other synthetic ion exchange resins (British Geological Survey, 2012; Gill et al.,2004 ; Hendrickson \& Vik, 1984; Jagtap et al., 2012; R. Maheshwari, 2006; Tembhurkar \& Dongre, 2006; Thole, 2013). Brick, bone char, fly ash, serpentine, red mud, waste mud, rice husk, kaolinite, bentonite, charfines, ceramic etc. are some of the other adsorbents used for removing fluoride from groundwater (Çengeloğlu et al., 2002; Chen et al., 2010; Chidambaram et al., 2004; Ganvir \& Das, 2011; Kemer et al., 2009; Loganathan et al., 2013; W. Ma et al. , 2008; Y. Ma et al. , 2011; Medellin-Castillo et al., 2007; Sarkar et al., 2006; Srimurali et al. , 1998; Tor et al. , 2009; Yadav et al., 1999). The effective removal of fluoride depends on the initial concentration of fluoride, $\mathrm{pH}$, contact time, operating temperature, type of adsorbent and its particle size (Feenstra et al., 2007; Mann \& Mandal,2014; Piddennavar \& Krishnappa, 2013). This technique is widely used due to convenience, ease of operation, simplicity of design, and for economic and environmental reasons (Feenstra et al., 2007; Habuda-Stanić et al., 2014). Activated alumina and bone char have been extensively used in many large scale defluoridation projects like in a water purification facility in Kansas utilizes activated alumina and in various other fluoride treatment facilities in India, Tanzania and Kenya due to very high sorption capacity of fluoride (Feenstra et al., 2007; Piddennavar \& Krishnappa, 2013; Susheela, 2001). Adsorption has certain limitations such as reduced adsorption capacity of the adsorbent on continuous usage, narrow $\mathrm{pH}$ range of operation, need for frequent regeneration, sludge generation problems and the cost of material (British Geological Survey, 2012; Habuda-Stanić et al., 2014; Loganathan et al., 2013; Piddennavar \& Krishnappa, 2013) makely it difficult to manage process at distributed small scales.

\section{Reverse osmosis}

Membranes can remove a large spectrum of contaminants from water such as pathogens, turbidity, heavy metals, salinity, natural and synthetic organics and hardness. The membranes requires little maintenance and work under wide $\mathrm{pH}$ range (R. Maheshwari, 2006; U.S. 
Environmental Protection Agency(USEPA), 2002). The US EPA, 2003, recommended reverse osmosis (RO) as one of the best available defluoridation technologies. RO membrane rejects ions based on size and electrical charge and could remove greater than $90 \%$ of fluoride from water (Gill et al.,2004 ; Hindin et al., 1968). Nano filtration membranes work particularly well due to its diffusional behaviour for fluoride rejection, its high hydraulic permeability and high selectivity for rejection of fluoride (Pontié et al., 2006). A particular advantage of NF membranes is that in Reverse Osmosis virtually everything is removed from water whereas NF membranes are selective and can function in a way that it doesn't remove the essential salts from water (Bason et al., 2006; Cervera et al., 2003; Diawara, 2008; Hu \& Dickson, 2006; R. Maheshwari, 2006; Szymczyk \& Fievet, 2005; Szymczyk et al., 2006; Yadav et al., 1999). But the membrane process incurs huge water losses as brine, have high capital cost, are very energy intensive and generally requires remineralisation as a post treatment step (Hindin et al., 1968; R. Maheshwari, 2006; U.S. Environmental Protection Agency(USEPA), 2002).

\section{Ion exchange process}

Ion exchange is a process in which ions of one substance are replaced by similar charged ions of other substance. Various anion exchange resins have been used for fluoride removal. Most commonly used fluoride exchange resins are degreased and alkali treated bone, inorganic ion exchangers, Tricalcium phosphate, Fluorex, Serpentine, Carbon exchanger like defluoron s1 , Carbion, Defluoron 2, Saw dust carbon, polystyrene cation exchange resin etc. (Helmenstine,2015; Jamhour, 2005; Khichar \& Kumbhat, 2015; Nagendra Rao, 2003). Ion exchange resins produce large amount of sludge and require regular regeneration making it hard to maintain at small scales. Further, the resins are very complex, contamination prone and expensive (Kumar \& Gopal, 2000; Tomar \& Kumar, 2013).

\section{Challenges with pump and treat defluoridation techniques:}

The literature above suggests that there is a diverse range of pump and treat methods available for fluoride removal from water, but most of these techniques are site specific, energy intensive, require ongoing monitoring and skilled operation, and are difficult to operate at decentralized scale (Teutsch et al., 1996). Millions of dollars have been spent around the globe to mitigate fluoride problem in drinking water by utilizing various households and community level solutions (Brindha et al., 2011; British Geological Survey, 2012; Dahi et al., 1996; Dysart ,2008 ; Fawell \& Bailey, 2006; Feenstra et al., 2007; Gill et al.,2004; Khichar \& Kumbhat, 2015; Loganathan et al., 2013; Mackay \& Cherry, 1989; R. Maheshwari, 2006; Majumdar, 2011; Mohapatra et al., 2009; Pontié et al., 2006; Thole, 2013). But in most cases only limited success was achieved (Gill et al., 2004; Padmasiri, 2000; Piddennavar \& Krishnappa, 2013). A study by National Research Council, USA in 1994 found that 69 out of 77 treatment sites using Pump and treat had not met up clean-up goals (National Research Council,1994; National Research Council,2005 ; Henderson \& Demond, 2007) due to one or combination of following reasons:

- Constant monitoring of the process is required to maintain the optimum $\mathrm{pH}$ range, temperature, optimum dose of adsorbent or resin required at a particular fluoride concentration and various other factors.

- Generated sludge is toxic and requires proper disposal, which can otherwise pose a 
huge threat to the society.

- Some adsorbent materials impart change in natural taste of water (red mud, waste mud, rice husk, kaolinite, bentonite, and charfines, ceramic). Bone char though has high sorption capacity, it is not preferred due to religious norms in many parts of the world with fluoride problem.

- The membranes are very expensive require high energy use and skilled operations.

- Long-term operation is often expensive due to the high energy used to pump and treat large volumes of water, and effluent disposal costs (National Research Council, 2005).

- Fluoride is a type of diffuse contamination which is generally rural in nature which makes the implementation of the technology even more difficult due to lack of education in rural communities (Thiruvenkatachari et al., 2008).

\section{IN-SITU DEFLUORIDATION}

In-situ defluoridation involves removal of fluoride from groundwater within the aquifer, instead of pumping water for treatment on the ground. In-situ remediation of fluoride has been seen as a potential solution to all the problems enlisted above. It is a cost effective, long term solution, no waste generation and requires little maintenance (Teutsch et al., 1996; Thiruvenkatachari et al., 2008; Tredoux et al., 2004; United States Environmental Protection Agency(USEPA), 2002). In-situ remediation techniques for contaminated groundwater have successfully been utilized to contain point source plumes. For a nonpoint contaminant of natural origin like fluoride in groundwater, some in situ treatment processes like Permeable reactive barriers might offer a solution for the rural communities discounting the operation and management at very small scale and the risk associated with that.

\section{Permeable reactive barrier (PRB)}

A PRB is an in situ, permeable treatment zone filled with reactive material(s) designed to intercept and remediate a contaminant plume as presented in fig. 1 (Gavaskar et al., 2000; Kimberly, 2015 ; Teutsch et al., 1996; The Interstate Technology \& Regulatory Council PRB: Technology Update Team, 2011; Thiruvenkatachari et al., 2008; Weiss et al., 1998). Permeable reactive barrier have low energy demands, obligates the need to manage the waste generated from treatment of contaminated water, and can simultaneously remediate multiple contaminants (D. W. Blowes et al., 2000; D. Blowes et al., 1995; Henderson \& Demond, 2007; Liu et al., 2013; Savard et al., 2010; Scherer et al., 2000; Wilson \& Mackay, 1995). According to USEPA $2002 \& 2005$, it also serves as a water resource conservation method as no water is removed from the aquifer and all water that passes through the PRB is returned to the native aquifer in a cleaner form. (USEPA, 2009; Henderson \& Demond, 2007; Liu et al., 2013; Savard et al., 2010; Scherer et al., 2000; Wilson \& Mackay, 1995) Once installed, PRB does not require above ground facilities or energy inputs, and it can take advantage of the in situ groundwater flow to bring the contaminants in contact with the reactive materials (Liu et al., 2013; Savard et al., 2010). Therefore, PRB's present a promising fluoride remediation option as they are designed to operate in situ for years with little or no maintenance (Gillham \& O'Hannesin, 1994; Gu et al., 1999; Kresic, 2008; Roehl et al., 2005). 


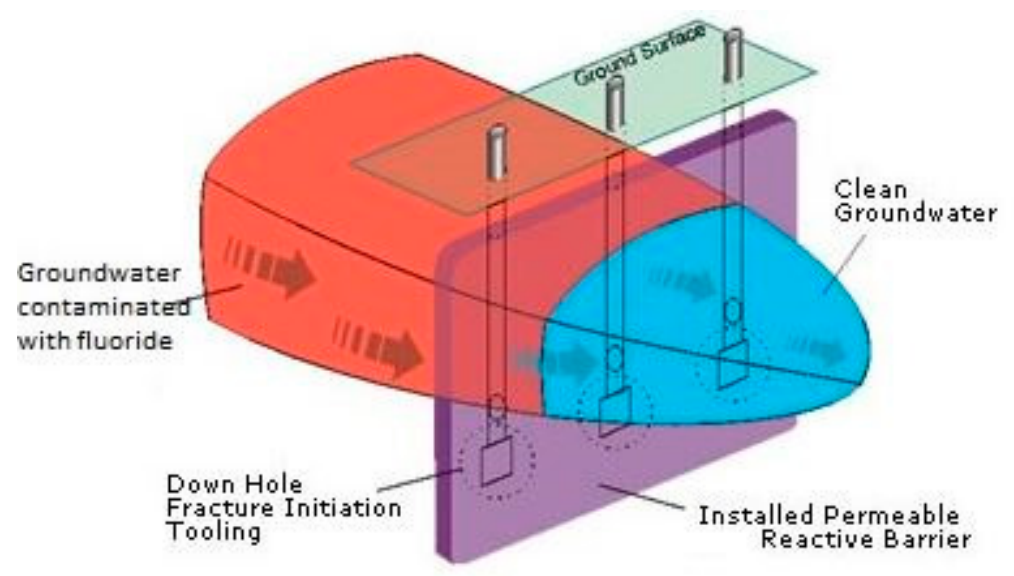

fig.1 A typical Permeable Reactive Barrier

Since its conception in the late 1980s, PRB technology has become an accepted practice for groundwater remediation and have been successfully used for a wide variety of reducible contaminants, ranging from heavy metals to halogenated hydrocarbons (Baric et al., 2012; Burris et al., 1998; Cantrell et al., 1995; Matheson \& Tratnyek, 1994; Sims et al., 1992; Suflita, 1989; Vogan et al., 1999). Several key agencies like ITRC, USEPA's Remediation Technologies Development Forum (RTDF), DOD and the US Department of Energy (DOE) have participated in development of PRB's. Site selection for PRB requires information regarding geology and microbiological characteristics of the aquifer (USEPA,.2009; Powell et al., 1998; Suflita, 1989). A PRB can be only be deployed on a site which includes a homogenous or permeable aquifer, a low groundwater gradient, no free product, no soil containment and an easily degraded, extracted or immobilized containment.

\section{PRB's in context of defloridation}

During our literature search, we did not find any study reporting PRB for in situ fluoride removal from groundwater but there have been some laboratory scale batch, column and pilot tests conducted to explore the potential use of PRB's for fluoride removal. Turner et.al 2008 conducted a pilot test using calcite as a substrate for PRB to remove fluoride from underground water polluted by spent potliner leachate (SPL), a waste derived from the aluminium smelting process (Turner et al., 2008). At the hydro aluminium smelter near Kurri Kurri, NSW, Australia, SPL was dumped by previous owners in an unlined waste repository from 1969 to 1992 resulting in contamination of the local groundwater aquifer with high levels of fluoride, cyanide (complexed), sodium, sulphate and chloride. They utilized $\mathrm{CO}_{2}$ to maintain a neutral $\mathrm{pH}$ and concluded that calcite substantially removes fluoride from groundwater polluted with SPL (Turner et al., 2008). A batch and column test was also done to test an adsorbent prepared from volcanic ash soil (VAS) as a suitable PRB material for removing fluoride from groundwater. The paper focused on removal of fluoride with the help of in situ permeable reactive barriers and has successfully concluded that VAS could also be used as suitable adsorbent in a PRB (Shinohara \& Iwasaki, 2014).

All the developments listed in literature on use of PRB's have focused on point source of contamination and no particular emphasis has been laid on non-point source of contamination. It has been established in literature that non-point source pollution is harder to manage than point source pollution (Harvey, 2015 ; Nienaber, 2015; Siegrist et al., 1998). WRCA, 2004 report suggested the use of in situ biological nitrification (ISBD), the nitredox system, multi electrode system or a circular barrier wall to remediating the groundwater contaminated with non-point source of pollution (R. Ma et al., 2013). Table 2 lists the case studies available in literature where use of PRB has been explored as a remediation option for certain non-point 
source contaminants. Various modified configurations of PRB's have also been utilised for diverse range of situations to remediate diffusely polluted aquifers.

Table 2: Case studies utilising PRB as a remediation option for non-point source contaminants.

\begin{tabular}{|c|c|c|c|c|}
\hline$\overline{\text { Contaminant }}$ & Source & PRB & Additional Points & References \\
\hline Cadmium & $\begin{array}{l}\text { It is released } \\
\text { into the } \\
\text { environment } \\
\text { through } \\
\text { mining and } \\
\text { smelting. }\end{array}$ & $\begin{array}{l}\text { Various In situ } \\
\text { Permeable reactive } \\
\text { barriers have been } \\
\text { installed to remediate } \\
\text { cadmium. Fly ash has } \\
\text { also been tested as a } \\
\text { suitable adsorbent. }\end{array}$ & $\begin{array}{l}\text { It was concluded } \\
\text { that PRB could } \\
\text { achieve a long } \\
\text { term efficiency by } \\
\text { preventing river } \\
\text { pollution for } \\
\text { several months. }\end{array}$ & $\begin{array}{l}\text { (Di Natale et al., 2008; Rostami \& } \\
\text { Silverstrim, 2000) }\end{array}$ \\
\hline Phosphorous & $\begin{array}{l}\text { Pollution } \\
\text { from } \\
\text { agriculture }\end{array}$ & $\begin{array}{l}\text { Remedial strategies to } \\
\text { remove dissolved P } \\
\text { from soil water and } \\
\text { shallow groundwater } \\
\text { flow paths using a } \\
\text { permeable reactive } \\
\text { barrier filled with } \\
\text { iron-coated sand }\end{array}$ & $\begin{array}{l}\text { Permeable } \\
\text { reactive barriers } \\
\text { are seen as a } \\
\text { potential } \\
\text { remediation } \\
\text { option in this field } \\
\text { and thereby are } \\
\text { further being } \\
\text { explored. }\end{array}$ & (Buda et al., 2012) \\
\hline Chromium & $\begin{array}{l}\text { Steelworks, } \\
\text { chromium } \\
\text { electroplatin } \\
\text { g, leather } \\
\text { tanning and } \\
\text { chemical } \\
\text { manufacturi } \\
\text { ng produce } \\
\text { high } \\
\text { chromium } \\
\text { wastes. }\end{array}$ & $\begin{array}{l}\text { The high } \\
\text { effectiveness of } \\
\text { Cr(VI)- polluted } \\
\text { groundwater removal } \\
\text { by Fe0-PRBs in the } \\
\text { laboratory and field } \\
\text { has been reported by } \\
\text { many researchers }\end{array}$ & $\begin{array}{l}\text { Chromium } \\
\text { concentrations } \\
\text { have been reduced } \\
\text { to } \\
\text { less than } 0.01 \\
\mathrm{mg} / \mathrm{L} \text {, much less } \\
\text { than drinking } \\
\text { water } \\
\text { limits }\end{array}$ & $\begin{array}{l}\text { (Cheng et al., 2010; Flury et al., } \\
\text { 2009; Galán et al., 2005; Golder } \\
\text { et al., 2007; Gonzalez et al., 2005; } \\
\text { Lee et al., 2003; Loyaux- } \\
\text { Lawniczak et al., 2001; Lu et al., } \\
\text { 2012; Pratt et al., 1997; Valko, et } \\
\text { al., 2005; Verma et al., 2006). }\end{array}$ \\
\hline
\end{tabular}

\section{Modified PRB's}

\section{$\underline{\text { Passive interceptor wells }}$}

In 1995 Wilson and MacKay (Wilson \& Mackay, 1995) proposed the use of passive interceptor wells as a PRB. Single or multiple rows of wells are installed across a contaminated plume and interception of the plume is achieved by the cumulative effects of convergence of groundwater flow to open wells from the up-gradient direction and subsequent divergence of groundwater flow down-gradient from the wells. Reactants or nutrients, which induce or enhance degradation reactions, are introduced to the groundwater via the wells. This results in a decrease in contaminant concentration down-gradient of the interceptor wells. According to ITRC in 2000, the main limitations of passive interceptor wells are the clogging of the aquifer around the injection wells and/or transport limitations of reactants to locations of contamination. This technology could be applied to remove any non-point source contaminant and may be helpful for remediating fluoride as well (Simon \& Meggyes, 2000). 


\section{Virtual PRB's with Overlapping Circulations Cells}

A unique hybrid permeable reactive barrier system was developed by IEG Technologies UK Ltd that intercept the groundwater plume before it discharges to surface water. The treatment system design included multiple overlapping PRBs to intercept and treat the contaminated plume of water at various depths in the shallow aquifer as presented in fig. 3. A monitoring program was implemented to determine the effectiveness of both PRBs, and potential changes to site groundwater flow. Similar system can be utilised to remediate the fluoride contaminated aquifer (IEG Technologies UK Ltd, 2006).

\section{$\underline{\text { Horizontal and Vertical PRB's }}$}

Another variation of PRB design is use of horizontal permeable reactive barriers as well as vertical barriers around the withdrawal well. This technology has not been researched much but holds significant potential as it limits the contaminated groundwater from all side in the well (Siegrist et al., 1998). Siegrist et al, 1998 evaluated the feasibility of creating horizontal treatment barriers by employing hydraulic fracturing for emplacement of chemically reactive solids. The results of this work was very positive regarding the performance of horizontal barriers and the estimated costs for a typical application are comparably low at only $\$ 30 / \mathrm{m}$. A PRB composed of a mixture of zero valent iron (ZVI) and native sediments was also placed on the bottom of Ashumet Pond on Cape Cod, Massachusetts, to reduce the load of phophate to the pond from the discharge of a treated wastewater groundwater plume(fig. 4). Data collected during the first 2 years after emplacement of the PRB indicate that the barrier reduced phosphate flux by as much as $95 \%$ (McCobb et al, 2009).

\section{PRB's adsorbent materials}

Most of the PRB's installed during 1996-2006 used iron based adsorbents. In 2004, out of 200 PRBs worldwide, 120 were iron based (90 in the United States) (Scherer et al., 2000). Zero valent iron, ZVI $\left(\mathrm{Fe}^{0}\right)$ has been found to be a strong chemical reductant as its reaction can proceed in situ under normal groundwater conditions and is able to convert many mobile oxidized oxyanions and oxy cations into immobile forms, breaks down chlorinated organic compounds (Hashim et al., 2011; Matheson et al., 1994; Roberts et al., 1996) reduces many halogenated methane's, ethane, ethene and other halogenated compounds at ambient temperatures, remediate groundwater contaminated by COCs (Baric et al., 2012; Wilkin et al., 2014) nitrate (Baric et al., 2012; Suthar et al., 2009; Tarkalson et al., 2006; Wick et al., 2012), arsenic (R. C. Maheshwari et al.,2006; Liu et al., 2013), and heavy metals (Lu et al., 2012). Another study by USEPA in 2002 conducted on around 50 PRB sites across US Canada and Europe revealed that zero valiant iron is used in large no. of occasions. ITRC has compiled various pilot scale operations in 2011 that have been done to remediate nitro benzenes from groundwater. Enhanced degradation of aliphatic hydrocarbons by batch and column test has been observed by using iron as the reactive media (Gillham \& O'Hannesin, 1994). Many PRB's installed at pilot and full scale during 1988-97 which have been applied for contaminants removal from groundwater in which 11 full scale and 11 pilot scale installations have been done in various states of United states by using iron as an adsorbent (Powell et al., 1998). 23 full Scale PRB of various designs use iron as a reactive media (Henderson \& Demond, 2007; Scherer et al., 2000). The U.S. Environmental Protection Agency (EPA) designated the ZVI PRB a standard remediation technology in 2002 (U.S. Environmental Protection Agency(USEPA), 2002). 
Iron salts have also shown potential to remove fluoride from water. Raul et al 2012 presented removal of fluoride from water using iron oxide-hydroxide nanoparticles. It have been found to be a potential adsorbent for the removal of fluoride from water with a maximum sorption capacity of the sorbent to be $16.70 \mathrm{mg}$ for fluoride at room temperature (Jahin,2014; Raul et al., 2012). Similarly, Fluoride can also be treated with a complex of Fe and Al and the fluoride level can be reduced from $10 \mathrm{mg} / 1$ to $0.01 \mathrm{mg} / 1$ (Zhu et al., 2011). CY Tsai et al 1999 removed fluoride from water with the help of iron coated spent catalyst whose removal capacity can be increased by further coating with iron salts. These catalysts are regenerated 2 to 3 time before they are wasted and also some researchers have studied the feasibility of utilizing them as adsorbent to remove sulphide from water (Tsai \& Liu, 1999). In addition, most of the sorbent material that have been used for fluoride removal in pump and treatment arrangment can potentially be utilised in PRB's as well.

\section{Challenges for PRB's}

Less data is available on the details of the reactive and hydraulic performance of PRBs compared to the large number of full-scale PRB application around the world constructed to remediate groundwater. Although there are over 200 PRBs operating, there was sufficient specific public information on field operating conditions and performance issues for only about 40. Utilizing this limited database, classes of possible failure modes of PRBs were delineated as listed below ( U.S. Environmental Protection Agency(USEPA), 2009; Higgins \& Olson, 2009; Phillips et al., 2010; Suflita, 1989; Thiruvenkatachari et al., 2008; U.S. Environmental Protection Agency(USEPA), 2002; Warner et al., 2005; Wilkin et al., 2014).

- Loss of reactivity after several years

- Several installed PRB's have reported problems in design itself. Clogging and reactivity loss is not a major issue.

- Lack of adequate technical expertise among consultants and regulators.

- It may sometimes leads to inadequate decontamination due to lack of monitoring.

- If Permeable Reactive Barriers are ineffective to remediate groundwater and thereby water has impurities then an additional cost of application of pump and treat Method is incorporated.

\section{Alternative in-situ technologies}

In addition to permeable reactive barriers (O'Hannesin \& Gillham, 1998), there are various other in situ technologies such as Vacuum vaporizer well (UVB technology), Groundwater circulation well Technology (GZB technology), air sparging and In-well vapour stripping (Herrling, 1991; Herrling \& Stamm, 1992; Herrling \& Stamm, 1994), that can be utilised for in-situ contaminant remediation. But these techniques can only be utilized for volatile contaminants, so cannot be used to remove fluoride from water. (Reddy et al., 1995; Kulakow,2015 ; Miller \& Roote, 1997; Scholz \& Stamm, 1997; Scholz et al., 1998; Simon \& Meggyes, 2000)

\section{CONCLUSIONS}

Various Pump \& treat methods are the conventionally used defluoridation techniques due to perceived convenience, ease of operation, simplicity of design, and for economic and environmental reasons. But most of these techniques are very site specific, require ongoing monitoring and maintenance, generate large amount of solid or liquid waste, which makes it 
very difficult to implement and maange at household or community scale due to lack of centralized infrastructure.

This literature review suggests that in situ defluoridation could be a possible solution for the problems encountered by pump and treat defluoridation techniques. In situ processes which involves treatment of groundwater directly instead of pumping water ex-situ is a cost effective, long term, energy efficient, obligates the need for sludge management and requires less maintenances. Permeable reactive barriers is seen as the most appropriate option as it is in use for wide range removal of contaminants ranging from heavy metals to halogenated carbon and is a major area of research.

Iron is the most researched adsorbent for use in PRB's worldwide. Most PRB's have been utilised to treat point sources of contamination. Three modified designs of PRB's, ie passive interceptor wells, overlapped PRB's, horizontal \& vertical PRB's have been used for various non-point source contaminants, and could possibly be used for defluoridation as well. PRB's like any technical advancement also possess several problems like loss of reactivity after several years and also may lead to inadequate decontamination but it excludes a number of problems encountered by pump and treat defluoridation techniques and thereby should be explored in more depth as a possible option for the defluoridation of contaminated aquifers.

\section{REFERENCES}

American Public Health Association. (2008). Community water fluoridation in the United States. Policy Statement Database.Washington, DC, USA: APHA,

Baric, M., Majone, M., Beccari, M., \& Papini, M. P. (2012). Coupling of polyhydroxybutyrate (PHB) and zero valent iron (ZVI) for enhanced treatment of chlorinated ethanes in permeable reactive barriers (PRBs). Chemical Engineering Journal, 195, 22-30.

Bason, S., Ben-David, A., Oren, Y., \& Freger, V. (2006). Characterization of ion transport in the active layer of RO and NF polyamide membranes. Desalination, 199(1), 31-33.

Blowes, D. W., Ptacek, C. J., Benner, S. G., McRae, C. W., Bennett, T. A., \& Puls, R. W. (2000). Treatment of inorganic contaminants using permeable reactive barriers. Journal of Contaminant Hydrology, 45(1), 123137.

Blowes, D., Ptacek, C., Bain, J., Waybrant, K., \& Robertson, W. (1995). Treatment of mine drainage water using in situ permeable reactive walls. Proc.Sudbury '95-Mining and the Environment may, , 979-987.

Brindha, K., Rajesh, R., Murugan, R., \& Elango, L. (2011). Fluoride contamination in groundwater in parts of nalgonda district, andhra pradesh, india. Environmental Monitoring and Assessment, 172(1-4), 481-492.

$\begin{array}{lll}\text { British } & \text { Geological } & \text { (2012). Fluoride }\end{array}$ groundwater.http://www.bgs.ac.uk/research/groundwater/health/fluoride.html

Buda, A. R., Koopmans, G. F., Bryant, R. B., \& Chardon, W. J. (2012). Emerging technologies for removing nonpoint phosphorus from surface water and groundwater: Introduction. Journal of Environmental Quality, 41(3), 621-627.

Burris, D. R., Allen-King, R. M., Manoranjan, V. S., Campbell, T. J., Loraine, G. A., \& Deng, B. (1998). Chlorinated ethene reduction by cast iron: Sorption and mass transfer. Journal of Environmental Engineering, 124(10), 1012-1019. 
Canadian Dental Association. (2012). CDA position on use of fluorides in caries prevention. Ottawa, ON: CDA,

Canadian Dental Association. (2013). CDA Position on use of Fluorides in Caries Prevention.2012,

Cantrell, K. J., Kaplan, D. I., \& Wietsma, T. W. (1995). Zero-valent iron for the in situ remediation of selected metals in groundwater. Journal of Hazardous Materials, 42(2), 201-212.

Carmona, R. (2004). Surgeon general statement on community water fluoridation. United States Department of Health and Human Services,

Çengeloğlu, Y., Kır, E., \& Ersöz, M. (2002). Removal of fluoride from aqueous solution by using red mud. Separation and Purification Technology, 28(1), 81-86.

Cervera, J., García-Morales, V., \& Pellicer, J. (2003). Ion size effects on the electrokinetic flow in nanoporous membranes caused by concentration gradients. The Journal of Physical Chemistry B, 107(33), 8300-8309.

Chen, N., Zhang, Z., Feng, C., Li, M., Zhu, D., Chen, R., et al. (2010). An excellent fluoride sorption behavior of ceramic adsorbent. Journal of Hazardous Materials, 183(1), 460-465.

Cheng, Y., Yan, F., Huang, F., Chu, W., Pan, D., Chen, Z., et al. (2010). Bioremediation of cr (VI) and immobilization as cr (III) by ochrobactrum anthropi. Environmental Science \& Technology, 44(16), 63576363.

Chidambaram, S., Ramanathan, A., \& Vasudevan, S. (2004). Fluoride removal studies in water using natural materials: Technical note. Water SA, 29(3), 339-344.

Cross, D. (2013). Water fluoridation as mass medication.

Dahi, E., Mtalo, F., Njau, B., \& Bregnhøj, H. (1996). Defluoridation using the nalgonda technique in tanzania. 22nd WEDC Conference,

Di Natale, F., Di Natale, M., Greco, R., Lancia, A., Laudante, C., \& Musmarra, D. (2008). Groundwater protection from cadmium contamination by permeable reactive barriers. Journal of Hazardous Materials, 160(2), 428434.

Diawara, C. K. (2008). Nanofiltration process efficiency in water desalination. Separation \& Purification Reviews, 37(3), 302-324.

Dysart, A.(2008). Investigation of Defluoridation Options for Rural and Remote Communities, CRC for Water Quality and Treatment

Edmunds, W. M., \& Smedley, P. L. (2013). Fluoride in natural waters. Essentials of medical geology (pp. 311336) Springer.

Fawell, J. K., \& Bailey, K. (2006). Fluoride in drinking-water World Health Organization.

Feenstra, L., Vasak, L., \& Griffioen, J. (2007). Fluoride in groundwater: Overview and evaluation of removal methods. Internat.Groundwater Res.Assess.Centre, Report no.SP, 1

Flury, B., Frommer, J., Eggenberger, U., Mäder, U., Nachtegaal, M., \& Kretzschmar, R. (2009). Assessment of long-term performance and chromate reduction mechanisms in a field scale permeable reactive barrier.Environmental Science \& Technology, 43(17), 6786-6792.

Galán, B., Castañeda, D., \& Ortiz, I. (2005). Removal and recovery of cr (VI) from polluted ground waters: A comparative study of ion-exchange technologies. Water Research, 39(18), 4317-4324. 
Ganvir, V., \& Das, K. (2011). Removal of fluoride from drinking water using aluminum hydroxide coated rice husk ash. Journal of Hazardous Materials, 185(2), 1287-1294.

Gavaskar, A., Gupta, N., Sass, B., Janosy, R., \& Hicks, J. (2000). Design Guidance for Application of Permeable Reactive Barriers for Groundwater Remediation,

Gill, T., Tiwari, S., \& Kumar, P. A.(2004). A review on feasibility of conventional fluoride removal techniques in urban areas. International Journal of Environmental Research and Development.

Gillham, R. W., \& O'Hannesin, S. F. (1994). Enhanced degradation of halogenated aliphatics by zero-valent iron. Groundwater, 32(6), 958-967.

Golder, A. K., Chanda, A. K., Samanta, A. N., \& Ray, S. (2007). Removal of cr (VI) from aqueous solution: Electrocoagulation vs chemical coagulation. Separation Science and Technology, 42(10), 2177-2193.

Gonzalez, A. R., Ndung'u, K., \& Flegal, A. (2005). Natural occurrence of hexavalent chromium in the aromas red sands aquifer, california. Environmental Science \& Technology, 39(15), 5505-5511.

Gu, B., Phelps, T., Liang, L., Dickey, M., Roh, Y., Kinsall, B., et al. (1999). Biogeochemical dynamics in zerovalent iron columns: Implications for permeable reactive barriers. Environmental Science \& Technology, 33(13), 2170-2177.

Habuda-Stanić, M., Ravančić, M. E., \& Flanagan, A. (2014). A review on adsorption of fluoride from aqueous solution. Materials, 7(9), 6317-6366.

Harvey, J. K. (2015). Pollution sources: Point and nonpoint. from http://www.waterencyclopedia.com/Po$\underline{\text { Re/Pollution-Sources-Point-and-Nonpoint.html }}$

Hashim, M., Mukhopadhyay, S., Sahu, J. N., \& Sengupta, B. (2011). Remediation technologies for heavy metal contaminated groundwater. Journal of Environmental Management, 92(10), 2355-2388.

Helmenstine, A. M.(2015) How to remove fluoride from drinking water., from http://chemistry.about.com/od/chemistryhowtoguide/a/removefluoride.htm

Henderson, A. D., \& Demond, A. H. (2007). Long-term performance of zero-valent iron permeable reactive barriers: A critical review. Environmental Engineering Science, 24(4), 401-423.

Hendrickson, K., \& Vik, E. A. (1984). Adsorption in water treatment: Fluoride removal. Rapport () Norwegian Institute for Water Research.

Herrling, B. (1991). In situ groundwater remediation of strippable contaminants by vacuum vaporizer wells (UVB): Operation of the well and report about cleaned industrial sites.

Herrling, B., \& Stamm, J. (1992). Numerical results of calculated 3 D vertical circulation flows around wells with two screen sections for in situ or on-site aquifer remediation. Computational Mechanics Publ, Southampton(Engl)., 1, 483-493.

Herrling, B., \& Stamm, J. (1994). Hydraulic circulation system for in situ remediation of strippable contaminants and in situ bioreclamation (GZB/UVB method).

Higgins, M. R., \& Olson, T. M. (2009). Life-cycle case study comparison of permeable reactive barrier versus pump-and-treat remediation. Environmental Science \& Technology, 43(24), 9432-9438.

Hindin, E., Dunstan, G. H., \& Bennett, P. J. (1968). Water reclamation by reverse osmosis Technical Extension Service, Washington State University. 
Hu, K., \& Dickson, J. M. (2006). Nanofiltration membrane performance on fluoride removal from water. Journal of Membrane Science, 279(1), 529-538.

Ibrahim, M., Asim Rasheed, S. M., \& Prabhakar, P. (2011). Effects of fluoride contents in ground water: A review. International Journal of Pharmaceutical Applications, 2(2), 128-134.

IEG Technologies UK Ltd. (2006). Innovative in situ treatment technologies for soil and groundwater. Retrieved from http://iegtechnologies.co.uk/files/pdfs/IEG\%20Groundwater\%20Circulation\%20Wells.pdf

Jagtap, S., Yenkie, M. K., Labhsetwar, N., \& Rayalu, S. (2012). Fluoride in drinking water and defluoridation of water. Chemical Reviews, 112(4), 2454-2466.

Jahin, H. S. (2014).Fluoride removal from water using nanoscale zero-valent iron (nzvi).

Jamhour, R. (2005). New inorganic ion-exchange material for the selective removal of fluoride from potable water using ion-selective electrode. American Journal of Environmental Sciences, 1(1), 1-4.

Jha, S. K., Mishra, V. K., Sharma, D. K., \& Damodaran, T. (2011). Fluoride in the environment and its metabolism in humans. Reviews of environmental contamination and toxicology volume 211 (pp. 121-142) Springer.

Kemer, B., Ozdes, D., Gundogdu, A., Bulut, V. N., Duran, C., \& Soylak, M. (2009). Removal of fluoride ions from aqueous solution by waste mud. Journal of Hazardous Materials, 168(2), 888-894.

Khichar, M., \& Kumbhat, S. (2015). Defluoridation-A review of water from aluminium and alumina based compound. Ijcs, 2(5), 04-11.

Kimberly, A. W. (2015), Permeable reactive barriers- A green technology., from http://www.frtr.gov/pdf/meetings/may10/presentations/wilson-presentation.pdf

Kresic, N. (2008). Groundwater resources: Sustainability, management, and restoration McGraw Hill Professional.

Kulakow, P.(2015). A guide to in-well vapor extraction adapted from "In-well vapor stripping", from https://www.engg.ksu.edu/CHSR/outreach/tosc/sites/docs/57th_vapor.pdf

Kumar, S., \& Gopal, K. (2000). A review on fluorosis and its preventive strategies. Indian Journal of Environmental Protection, 20(6), 430-440.

Lee, T., Lim, H., Lee, Y., \& Park, J. (2003). Use of waste iron metal for removal of cr (VI) from water. Chemosphere, 53(5), 479-485.

Liu, S., Zhao, Z., Li, J., Wang, J., \& Qi, Y. (2013). An anaerobic two-layer permeable reactive biobarrier for the remediation of nitrate-contaminated groundwater. Water Research, 47(16), 5977-5985.

Loganathan, P., Vigneswaran, S., Kandasamy, J., \& Naidu, R. (2013). Defluoridation of drinking water using adsorption processes. Journal of Hazardous Materials, 248, 1-19.

Loyaux-Lawniczak, S., Lecomte, P., \& Ehrhardt, J. (2001). Behavior of hexavalent chromium in a polluted groundwater: Redox processes and immobilization in soils. Environmental Science \& Technology, 35(7), 1350-1357.

Lu, X., Li, M., Tang, C., Feng, C., \& Liu, X. (2012). Electrochemical depassivation for recovering fe 0 reactivity by $\mathrm{cr}$ (VI) removal with a permeable reactive barrier system. Journal of Hazardous Materials, 213, 355360. 
Lyengar, L.(1996). 22 technologies for fluoride removal.

Ma, R., Shi, J., \& Liu, J. (2013). FRFI model application in groundwater non-point source pollution evaluation: A case study in the luoyang basin of north henan province, china. Environmental Earth Sciences, 68(1), 4556.

Ma, W., Ya, F., Wang, R., \& Zhao, Y. (2008). Fluoride removal from drinking water by adsorption using bone char as a biosorbent. International Journal of Environmental Technology and Management, 9(1), 59-69.

Ma, Y., Shi, F., Zheng, X., Ma, J., \& Gao, C. (2011). Removal of fluoride from aqueous solution using granular acid-treated bentonite (GHB): Batch and column studies. Journal of Hazardous Materials, 185(2), 10731080 .

MacDonald, J. A., \& Kavanaugh, M. C. (1994). Restoring contaminated groundwater: An achievable goal? Environmental Science \& Technology, 28(8), 362A-368A.

Mackay, D. M., \& Cherry, J. A. (1989). Groundwater contamination: Pump-and-treat remediation. Environmental Science \& Technology, 23(6), 630-636.

Maheshwari, R. (2006). Fluoride in drinking water and its removal. Journal of Hazardous Materials, 137(1), 456463.

Maheshwari, R. C. (2006). Arsenic removal from water: a review. Asian Journal of Water, Environment and Pollution, 3(1), 133-139.

Majumdar, K. K. (2011). Health impact of supplying safe drinking water containing fluoride below permissible level on flourosis patients in a fluoride-endemic rural area of west bengal. Indian Journal of Public Health, 55(4), 303-308.

Mann, S., \& Mandal, A.(2014). Performance of low-cost adsorbents for the removal of fluoride ions-An overview. International Journal of Engineering Science and Innovative Technology (IJESIT).

Matheson, L. J., \& Tratnyek, P. G. (1994). Reductive dehalogenation of chlorinated methanes by iron metal. Environmental Science \& Technology, 28(12), 2045-2053.

Matsuura, T., \& Sourirajan, S. (1972). Studies on reverse osmosis for water pollution control. Water Research, 6(9), 1073-1086.

McCobb, T. D., LeBlanc, D. R., \& Massey, A. J. (2009). Monitoring the removal of phosphate from ground water discharging through a Pond-Bottom permeable reactive barrier. Groundwater Monitoring \& Remediation, 29(2), 43-55.

McDonagh, M. S., Whiting, P. F., Wilson, P. M., Sutton, A. J., Chestnutt, I., Cooper, J., et al. (2000). Systematic review of water fluoridation. BMJ (Clinical Research Ed.), 321(7265), 855-859.

Medellin-Castillo, N. A., Leyva-Ramos, R., Ocampo-Perez, R., Garcia de la Cruz, Ramon F, Aragon-Pina, A., Martinez-Rosales, J. M., et al. (2007). Adsorption of fluoride from water solution on bone char. Industrial \& Engineering Chemistry Research, 46(26), 9205-9212.

Mercola. (2015). 10 facts about fluoride you need to know. Retrieved http://articles.mercola.com/sites/articles/archive/2015/01/13/10-important-fluoridefacts.aspx

Miller, R. R., \& Roote, D. S. (1997). In-well vapor stripping Ground-Water Remediation Technologies Analysis Center. 
Mishra, S., Das, M., \& Dash, U. (2010). Review on adverse effects of water contaminants like arsenic, fluoride and phosphate and their remediation. J Sci Ind Res, 69, 249-253.

Mohapatra, M., Anand, S., Mishra, B., Giles, D. E., \& Singh, P. (2009). Review of fluoride removal from drinking water. Journal of Environmental Management, 91(1), 67-77.

Nagendra Rao, C. (2003). Fluoride and environment-a review. Proceedings of the Third International Conference on Environment and Health (Eds Bunch MJ, Suresh VM and Kumaran TV), York University, pp. $15-17$.

National Research Council (US). Committee on Ground Water Cleanup Alternatives. (1994). Alternatives for ground water cleanup, National Academies Press., Washington, DC,USA.

National Research Council.Committee on Source Removal of Contaminants in the Subsurface (2005). Contaminants in the subsurface: Source zone assessment and remediation, National Academy Press, Washington, DC, USA.

Nienaber, C. J. Clean water act., 2015, from http://www.waterencyclopedia.com/Ce-Cr/Clean-Water-Act.html

O'Hannesin, S. F., \& Gillham, R. W. (1998). Long-Term performance of an in situ "Iron wall" for remediation of VOCs. Groundwater, 36(1), 164-170.

Oruc, N. (2008). Occurrence and problems of high fluoride waters in turkey: An overview. Environmental Geochemistry and Health, 30(4), 315-323.

Padmasiri, J. (2000). Effectiveness of domestic defluoridator in preventing fluorosis in kekirawa, sri lanka. Eli Dahi Sunsanee Rajchagool \& Nipaphan Osiriphan, , 91.

Phifer, M. A., Nichols, R. L., Sappington, F. C., Steimke, J. L., \& Jones, W. E. (2002). <br $\triangle$ GeoSiphon $^{T M}$ Ground water remediation system hydraulics. ( No. DE-AC09-96SR18500). U.S. Department of Energy:

Phillips, D., Nooten, T. V., Bastiaens, L., Russell, M., Dickson, K., Plant, S., et al. (2010). Ten year performance evaluation of a field-scale zero-valent iron permeable reactive barrier installed to remediate trichloroethene contaminated groundwater. Environmental Science \& Technology, 44(10), 3861-3869.

Piddennavar, R., \& Krishnappa, P. (2013). Review on defluoridation techniques of water. International Journal of Engineering and Sciences, 2(3), 86-94.

Pontié, M., Diawara, C., Lhassani, A., Dach, H., Rumeau, M., Buisson, H., et al. (2006). Water defluoridation processes: A review. application: Nanofiltration (NF) for future large-scale pilot plants. Advances in Fluorine Science, 2, 49-80.

Powell, R. M., Puls, R. W., Blowes, D., Gillham, R., \& Schultz, D. (1998). Permeable reactive barrier technologies for contaminant remediation. Nasa, (19990008853)

Pratt, A. R., Blowes, D. W., \& Ptacek, C. J. (1997). Products of chromate reduction on proposed subsurface remediation material. Environmental Science \& Technology, 31(9), 2492-2498.

Raul, P. K., Devi, R. R., Umlong, I. M., Banerjee, S., Singh, L., \& Purkait, M. (2012). Removal of fluoride from water using iron oxide-hydroxide nanoparticles. Journal of Nanoscience and Nanotechnology, 12(5), 39223930.

Roberts, A. L., Totten, L. A., Arnold, W. A., Burris, D. R., \& Campbell, T. J. (1996). Reductive elimination of chlorinated ethylenes by zero-valent metals. Environmental Science \& Technology, 30(8), 2654-2659. 
Roehl, K. E., Meggyes, T., Simon, F., \& Stewart, D. (2005). Long-term performance of permeable reactive barriers Gulf Professional Publishing.

Rostami, H., \& Silverstrim, T. (2000). In Situ Removal of Cadmium and Chromium from Groundwater using ZeoTech Reactive Barriers.Final Report for Period October 1999-April 2000.

Sarkar, M., Banerjee, A., Pramanick, P. P., \& Sarkar, A. R. (2006). Use of laterite for the removal of fluoride from contaminated drinking water. Journal of Colloid and Interface Science, 302(2), 432-441.

Savard, M. M., Somers, G., Smirnoff, A., Paradis, D., van Bochove, E., \& Liao, S. (2010). Nitrate isotopes unveil distinct seasonal $\mathrm{N}$-sources and the critical role of crop residues in groundwater contamination. Journal of Hydrology, 381(1), 134-141.

Scherer, M. M., Richter, S., Valentine, R. L., \& Alvarez, P. J. (2000). Chemistry and microbiology of permeable reactive barriers for in situ groundwater clean up. Critical Reviews in Microbiology, 26(4), 221-264.

Scholz, M., \& Stamm, J. (1997). Detailed 3-D field experiments with a groundwater circulation well for aquifer remediation. Groundwater@sAn Endangered Resource, pp. 113-119.

Scholz, M., Weber, O., Mohrlok, U., \& Eldho, T. (1998). Large scale experiments for in situ flushing using groundwater circulation wells: Identification of processes and limiting parameters. IAHS Publication(International Association of Hydrological Sciences), (250), 185-189.

Scholz, M., Mohrlok, U., \& Stamm, J. (1998). Detailed three-dimensional field experiment with a groundwater circulation well for in situ flushing. IAHS Publication(International Association of Hydrological Sciences), (250), 133-140.

Shinohara, T., \& Iwasaki, M. (2014). Investigation of permeable reactive barrier design parameters for remediating fluoride-contaminated groundwater using a volcanic ash soil adsorbent. 日本イオン交換学会 誌, 25(4), 256-261.

Siegrist, R., Lowe, K., Murdoch, L., Case, T., \& Pickering, D. (1998). Horizontal Treatment Barriers of FractureEmplaced Iron and Permanganate Particles.NATO/CCMS Pilot Study Special Session on Treatment Walls and Permeable Reactive Barriers,

Simon, F., \& Meggyes, T. (2000). Removal of organic and inorganic pollutants from groundwater using permeable reactive barriers. Land Contamination \& Reclamation, 8(2), 103-116.

Sims, J., Suflita, J., Russell, H., \& Boulding, J. (1992). In situ bioremediation of contaminated ground water.

Srimurali, M., Pragathi, A., \& Karthikeyan, J. (1998). A study on removal of fluorides from drinking water by adsorption onto low-cost materials. Environmental Pollution, 99(2), 285-289.

Suflita, J. (1989). Microbiological principles influencing the biorestoration of aquifers. US Environmental Protection Agency, Seminar Publication-Transport and Fate of Contaminants in the Subsurface. EPA/625/4-89/019, pp. 85-99.

Suthar, S., Bishnoi, P., Singh, S., Mutiyar, P. K., Nema, A. K., \& Patil, N. S. (2009). Nitrate contamination in groundwater of some rural areas of rajasthan, india. Journal of Hazardous Materials, 171(1), 189-199.

Suneetha, N., Rupa K, P., Sabitha, V., Kumar K, K., Mohanty, S., Kanagasabapathy A, S., \& Rao, P. (2008). Defluoridation of water by a one step modification of nalgonda technique. Ann Trop Med Public Healt, 1(56-8)

Susheela, A. (2001). Sound planning and implementation of fluoride and fluorosis mitigation programme in an endemic village. Int. Workshop on Fluoride in Drinking Water, 
Szymczyk, A., \& Fievet, P. (2005). Investigating transport properties of nanofiltration membranes by means of a steric, electric and dielectric exclusion model. Journal of Membrane Science, 252(1), 77-88.

Szymczyk, A., Sbaï, M., Fievet, P., \& Vidonne, A. (2006). Transport properties and electrokinetic characterization of an amphoteric nanofilter. Langmuir, 22(8), 3910-3919.

Tarkalson, D., Payero, J., Ensley, S., \& Shapiro, C. A. (2006). Nitrate accumulation and movement under deficit irrigation in soil receiving cattle manure and commercial fertilizer. Agricultural Water Management, 85(1), 201-210.

Tekle-Haimanot, R., Fekadu, A., Bushera, B., \& Mekonnen, Y. (1995). Fluoride levels in water and endemic fluorosis in ethiopian rift valley. Ngurdoto, Tanzania October 18-21, 1995, , 12.

Tembhurkar, A., \& Dongre, S. (2006). Studies on fluoride removal using adsorption process. Journal of Environmental Science \& Engineering, 48(3), 151-156.

Teutsch, G., Grathwohl, P., Schad, H., \& Werner, P. (1996). In-situ-Reaktionswände-ein neuer ansatz zur passiven sanierung von boden-und grundwasserverunreinigungen. Grundwasser, 1(1), 12-20.

The Interstate Technology \& Regulatory Council PRB: Technology Update Team.(ITRC) (2011). Permeable reactive barrier: Technology update.

The Univerisity of Adelaide. (2012). Fluoride review guidelines - outcomes of fluoride consensus workshop 2012. Australian Research Centre for Population Oral Health (ARCPOH),

Thiruvenkatachari, R., Vigneswaran, S., \& Naidu, R. (2008). Permeable reactive barrier for groundwater remediation. Journal of Industrial and Engineering Chemistry, 14(2), 145-156.

Thole, B. (2013). Ground water contamination with fluoride and potential fluoride removal technologies for east and southern africa INTECH Open Access Publisher.

Tomar, V., \& Kumar, D. (2013). A critical study on efficiency of different materials for fluoride removal from aqueous media. Chem.Cent.J, 7(1), 1-15.

Tor, A., Danaoglu, N., Arslan, G., \& Cengeloglu, Y. (2009). Removal of fluoride from water by using granular red mud: Batch and column studies. Journal of Hazardous Materials, 164(1), 271-278.

Tredoux, G., Clarke, S., \& Cave, L. (2004). The feasibility of in situ groundwater remediation as a robust lowcost water treatment option. Water Research Commission Report, (1325/1), 04.

Tsai, C., \& Liu, J. (1999). Fluoride removal from water with iron-coated spent catalyst. Journal of the Chinese Institute of Environmental Engineering, 9(2), 107-114.

Turner, B. D., Binning, P. J., \& Sloan, S. W. (2008). A calcite permeable reactive barrier for the remediation of fluoride from spent potliner (SPL) contaminated groundwater| NOVA. the university of newcastle's digital repository.

U.S. Environmental Protection Agency(USEPA). (2002). Field applications of in situ remediation technologies: Permeable reactive barriers. Environmental Management Support, Inc., 8601 Georgia Avenue, Suite 500, Silver Spring, MD 20910, under contract 68-W-00-084, Work Assignment 006, with the U.S. Environmental Protection Agency.

United States Environmental Protection Agency. (2009). Water treatment technology feasibility support document for chemical contaminants for the second six-year review of national primary drinking water. regulations No. EPA 815-B-09-007 
Valko, M., Morris, H., \& Cronin, M. (2005). Metals, toxicity and oxidative stress. Current Medicinal Chemistry, 12(10), 1161-1208.

Verma, A., Chakraborty, S., \& Basu, J. (2006). Adsorption study of hexavalent chromium using tamarind hullbased adsorbents. Separation and Purification Technology, 50(3), 336-341.

Vogan, J., Focht, R., Clark, D., \& Graham, S. (1999). Performance evaluation of a permeable reactive barrier for remediation of dissolved chlorinated solvents in groundwater. Journal of Hazardous Materials, 68(1), 97108.

Warner, S. D., Longino, B. L., Zhang, M., Bennett, P., Szerdy, F. S., \& Hamilton, L. A. (2005). The first commercial permeable reactive barrier composed of granular iron: Hydraulic and chemical performance at 10 years of operation. Iahs Publication, 298, 32.

Weiss, H., Kopinke, F., Popp, P., \& Wunsche, L. (1998). In situ remediation research in a complexly contaminated aquifer: The SAFIRA test site at bitterfeld, germany. NATO/CCMS Pilot Study: Evaluation of Demonstrated and Emerging Technologies for the Treatment of Contaminated Land and Groundwater-Phase III.Special Session on Treatment Walls and Permeable Reactive Barriers, (229), 84-91.

Wick, K., Heumesser, C., \& Schmid, E. (2012). Groundwater nitrate contamination: Factors and indicators. Journal of Environmental Management, 111, 178-186.

Wilkin, R. T., Acree, S. D., Ross, R. R., Puls, R. W., Lee, T. R., \& Woods, L. L. (2014). Fifteen-year assessment of a permeable reactive barrier for treatment of chromate and trichloroethylene in groundwater. Science of the Total Environment, 468, 186-194.

Wilson, R. D., \& Mackay, D. M. (1995). A method for passive release of solutes from an unpumped well. Groundwater, 33(6), 936-945.

Yadav, S., Khan, T., Gupta, S., Gupta, A., \& Yadava, R. (1999). Fluorosis in india with special reference to rajasthan. Proceedings of the International Conference on Water, Environment, Ecology, Socioeconomics and Health Engineering (WEESHE), Seoul National University, pp. 3-10.

Yeung, C. A. (2008). A systematic review of the efficacy and safety of fluoridation. Evidence-Based Dentistry, 9(2), 39-43.

Zhu, H., Wang, G., Wang, H., \& Zhang, K. (2011). Removal of fluorine from water by using the synthetical ironaluminum hydroxide complexes. Electric Technology and Civil Engineering (ICETCE), 2011 International Conference on, pp. 6771-6773.

(C) 2017 by the authors; licensee Preprints, Basel, Switzerland. This article is an open access article distributed under the terms and conditions of the Creative Commons by Attribution (CC-BY) license (http://creativecommons.org/licenses/by/4.0/). 